Article

\title{
In Vivo and in Vitro Anti-Inflammatory Activity of Neorogioltriol, a New Diterpene Extracted from the Red Algae Laurencia glandulifera
}

Rim Chatter ${ }^{1, \dagger}$, Rym Ben Othman ${ }^{2, \dagger}$, Sameh Rabhi ${ }^{2}$, Maria Kladi ${ }^{3}$, Safa Tarhouni ${ }^{1}$, Constantinos Vagias ${ }^{3,}$, Vassilios Roussis ${ }^{3}$, Lamia Guizani-Tabbane ${ }^{2, \S}$, and Riadh Kharrat $^{1, \S}$

1 Unit of Biotoxines, Pasteur Institut of Tunis, 13, Place Pasteur, B.P. 74. 1002 Tunis-Belvedere, Tunisia; E-Mails: rimchatter@gmail.com (R.C.); satarhouni@yahoo.fr (S.T.); riadh.kharrat@pasteur.rns.tn (R.K.)

2 Laboratory of Immunopathology, Vaccinology and Molecular Genetics (LIVGM), WHO Collaborating Center for Research and Training in Leishmaniasis and International Associated Laboratory (LIA-CNRS), Pasteur Institut of Tunis, 13, Place Pasteur, B.P. 74. 1002 Tunis-Belvedere, Tunisia; E-Mails: rymbenothman@gmail.com (R.B.O.); rabhi_sameh@yahoo.fr (S.R.)

3 Department of Pharmacognosy and Chemistry of Natural Products, School of Pharmacy, University of Athens, Panepistimiopolis Zografou, Athens 15771, Greece; E-Mails: kladi@ pharm.uoa.gr (M.K.); vagias@ pharm.uoa.gr (C.V.); roussis@pharm.uoa.gr (V.R.)

$\dagger$ These authors contributed equally to this work.

* This author deceased on 12 May 2010.

$\S$ These authors contributed equally to this work.

* Author to whom correspondence should be addressed; E-Mail: lamia.guizani@ Pasteur.rns.tn; Tel.: +216-71-789-608; Fax: +216-71-791-833.

Received: 11 May 2011; in revised form: 3 June 2011 / Accepted: 5 July 2011 / Published: 22 July 2011

\begin{abstract}
Neorogioltriol is a tricyclic brominated diterpenoid isolated from the organic extract of the red algae Laurencia glandulifera. In the present study, the anti-inflammatory effects of neorogioltriol were evaluated both in vivo using carrageenan-induced paw edema and in vitro on lipopolysaccharide (LPS)-treated Raw264.7 macrophages. The in vivo study demonstrated that the administration of $1 \mathrm{mg} / \mathrm{kg}$ of neorogioltriol resulted in the significant reduction of carregeenan-induced rat edema. In vitro, our results show that neorogioltriol treatment decreased the luciferase activity in LPS-stimulated Raw264.7 cells, stably

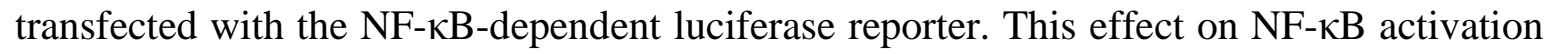
is not mediated through MAPK pathways. The inhibition of NF- $\kappa \mathrm{B}$ activity correlates
\end{abstract}


with decreased levels of LPS-induced tumor necrosis factor-alpha (TNF $\alpha$ ) present in neorogioltriol treated supernatant cell culture. Further analyses indicated that this product also significantly inhibited the release of nitric oxide and the expression of cyclooxygenase-2 (COX-2) in LPS-stimulated Raw264.7 cells. These latter effects could only be observed for neorogioltriol concentrations below $62.5 \mu \mathrm{M}$. To our knowledge, this is the first report describing a molecule derived from Laurencia glandulifera with anti-inflammatory activity both in vivo and in vitro. The effect demonstrated in vitro may be explained by the inhibition of the LPS-induced NF- $\mathrm{BB}$ activation and TNF $\alpha$ production. NO release and COX-2 expression may reinforce this effect.

Keywords: anti-inflammatory; neorogioltriol; Laurencia; TNF $;$ NF-кB; NO; COX-2; carrageenan

\section{Introduction}

Natural products derived from plants provide an interesting and promising source for isolating and developing therapeutic molecules to fight against various diseases, including inflammatory ones [1]. In this respect, different natural products derived from marine organisms have been reported to exhibit a broad spectrum of pharmacological activity, including anti-inflammatory effects [2,3].

During the process of inflammation, different cell types are recruited, including monocytes that differentiate locally into macrophages. This leads to the regulated production of various pro- and anti-inflammatory mediators including cytokines, such as $\mathrm{TNF} \alpha$, chemokines and inducible enzymes (COX-2 and iNOS) that play critical roles in controlling the inflammatory processes. The expression of most of these proteins is controlled, at least in part, through the activation of a conserved and ubiquitous transcription factor, NF- $\mathrm{B}$ which plays a key role in inflammatory response.

Several natural products with anti-inflammatory effects have been shown to target and modulate the NF- $\kappa \mathrm{B}$ signaling pathway, including a number of terpenoids [4,5]. Molecules belonging to this family were isolated from different marine organisms including coral, sponge and algae [3]. Algae, particularly red algae, represent a rich source of different secondary metabolites, the majority of which consists of acetogenins, halogenated diterpenes and sesquiterpenes [6-8]. Several molecules were derived from the genus Laurencia and have been shown to exhibit a number of different activities [9-11]. Using total extracts obtained from different algae, numerous studies have shown associated anti-inflammatory effects both in vivo [12,13] and in vitro [14,15]. However, to the best of our knowledge, purified molecules with anti-inflammatory effects have not yet been documented from the genus Laurencia.

Recently, we have isolated neorogioltriol, a new diterpene with analgesic activity [16] from the organic extract of the red algae Laurencia glandulifera. In this report we investigated the anti-inflammatory activity of this molecule both in vivo, experimenting on carrageenan-induced inflammation in the rat paw and in vitro, based on the expression of NF- $\mathrm{BB}$ and COX-2, as well as the release of TNF $\alpha$ and NO, from LPS-stimulated Raw264.7 macrophages. 


\section{Results and Discussion}

\subsection{Effect of Neorogioltriol on Carrageenan-Induced Paw Edema in Rats}

The carrageenan-induced paw edema model in rats, one of the well-established acute inflammatory models in vivo, was used to test the anti-inflammatory activity of neorogioltriol. In the control group, the intraplantar injection of $100 \mu \mathrm{L}$ of carrageenan $(0.6 \%)$ into the rat's hind paw induced a significant increase in paw edema (Table 1). This observation indicates the development of an inflammatory response and paw swelling (edema). The edema was present as early as one hour after carrageenan injection, progressed rapidly and persisted for at least $5 \mathrm{~h}$ after treatment. Both dexamethasone and ASA, used as positives controls, inhibited the oedematogenic response evoked by carrageenan in rats at all assessment times. However, as previously reported [17], the kinetics of the effect of both components was different: whereas the dexamethasone-associated effect was rapid and produced a $42 \%$ reduction of the edema after the first hour, the ASA-induced effect was slower (only $17 \%$ in the first hour), but reached a 59\% inhibition by the fifth hour. Treatment of rats with the neorogioltriol molecule at an intraperitoneal dose of $1 \mathrm{mg} / \mathrm{kg}$ significantly reduced paw swelling at all time points tested (Table 1). This reduction was about $28 \%$ after the first hour and reached a maximum of $58 \%$ at $3 \mathrm{~h}$ post injection. Moreover, a $1 \mathrm{mg} / \mathrm{kg}$ dose of neorogioltriol proved as effective as $300 \mathrm{mg} / \mathrm{kg}$ of ASA in reducing inflammation.

Using the carrageenan-induced paw edema model in rats, our results showed that the red algae-derived natural molecule neorogioltriol was able to reduce the formation of edema in a concentration- and time-dependent manner.

Table 1. Effect of neorogioltriol on carrageenan-induced paw edema in rats.

\begin{tabular}{|c|c|c|c|c|c|c|c|c|c|}
\hline \multicolumn{4}{|c|}{ Times after carageenan injection (h) } & \multicolumn{2}{|l|}{$1 \mathbf{h}$} & \multicolumn{2}{|l|}{$3 \mathbf{h}$} & \multicolumn{2}{|l|}{$5 \mathbf{h}$} \\
\hline \multirow{2}{*}{ Groups } & \multirow{2}{*}{ Treatment } & \multirow{2}{*}{$n$} & \multirow{2}{*}{$\begin{array}{c}\text { Dose } \\
(\mathrm{mg} / \mathrm{kg})\end{array}$} & EV & EI & EV & EI & EV & EI \\
\hline & & & & $\left(10^{-2} \mathrm{~mL}\right)$ & $(\%)$ & $\left(10^{-2} \mathrm{~mL}\right)$ & $(\%)$ & $\left(10^{-2} \mathrm{~mL}\right)$ & $(\%)$ \\
\hline Control & Control & 6 & - & $18.3 \pm 2.7$ & - & $56.3 \pm 5.8$ & - & $69 \pm 7.7$ & - \\
\hline \multirow{2}{*}{ Tests } & \multirow{2}{*}{ Neorogioltriol } & \multirow[t]{2}{*}{6} & 0.5 & $15.5 \pm 3.1$ & 15.3 & $42 \pm 5.5(*)$ & 33.3 & $49.1 \pm 6.1$ & 28.8 \\
\hline & & & 1 & $14.1 \pm 3(*)$ & 22.95 & $23.5 \pm 3.7(* * *)$ & 58 & $33 \pm 3.5(* *)$ & 52.27 \\
\hline \multirow{2}{*}{ References } & Aspirin (ASA) & 6 & 300 & $16.5 \pm 3.1$ & 9.83 & $25.1 \pm 6.7(* *)$ & 55.17 & $28.1 \pm 2.2(* *)$ & 59.27 \\
\hline & Dexamethasone & 6 & 1 & $9.83 \pm 1.8$ & 47.54 & $39.3 \pm 3.8(* * *)$ & 42.5 & $32.5 \pm 5.7(* * *)$ & 52.86 \\
\hline
\end{tabular}

Neorogioltriol $(0.5$ or $1 \mathrm{mg} / \mathrm{kg})$ was administrated one hour before the intraplantar carrageenan injection. Reference animals were treated with dexamethasone $(1 \mathrm{mg} / \mathrm{kg}$ ) or aspirin (ASA) (300 mg/kg); control animals received vehicle $(0.9 \% \mathrm{NaCl})$ used to re-suspend the different drugs. Six animals were used for each treatment group. The drugs were administrated by intraperitoneal injection. The edema volume (EV) was determined immediately before and 1,3 , and $5 \mathrm{~h}$ after the carrageenan injection. When needed, the edema inhibition (EI) was calculated. The percentage of inhibition in treated rats versus control was calculated using the following formula: EI $(\%)=\left(\left[\left(C_{\mathrm{t}}-C_{0}\right)\right.\right.$ control $-\left(C_{\mathrm{t}}-C_{0}\right)$ treated $] /\left(C_{\mathrm{t}}-C_{0}\right)$ control $) \times 100$ where $C_{\mathrm{t}}$ correspond to edema volume after carrageenan injection and $C_{0}$ correspond to edema volume before carrageenan injection. The values are expressed as the mean $\pm \mathrm{SD} ; * p<0.05 ; * * p<0.01 ; * * * p<0.001$ determined by Student's $t$ test compared with control. 


\subsection{Cell Viability}

Cytotoxic potential of neorogioltriol on Raw264.7 cells was tested using the MTT assay. Our result shows that in the presence of up to $250 \mu \mathrm{M}$ of neorogioltriol, Raw264.7 macrophages viability was not significantly lower than in non-treated cells. We find cytotoxicity only at the highest neorogioltriol concentration $(500 \mu \mathrm{M})$ which causes an optical density (OD) reduction of about $50 \%$.

Figure 1. Raw264.7 macrophages were either left untreated or were treated with various concentrations of neorogioltriol. The cytotoxic effects were recorded at an observation period of $24 \mathrm{~h}$ by using 3-(4,5-dimethylthiazol-2-yl)-2,5-diphenyl tetrazolium bromide (MTT) test as described under "Experimental Section". The cell number in each well was recorded in the form of optical density (OD). Data are expressed as means \pm SD of three independent experiments performed in triplicates. Results were analyzed by using one-way analysis of variance (ANOVA) with significance of $p<0.05$.

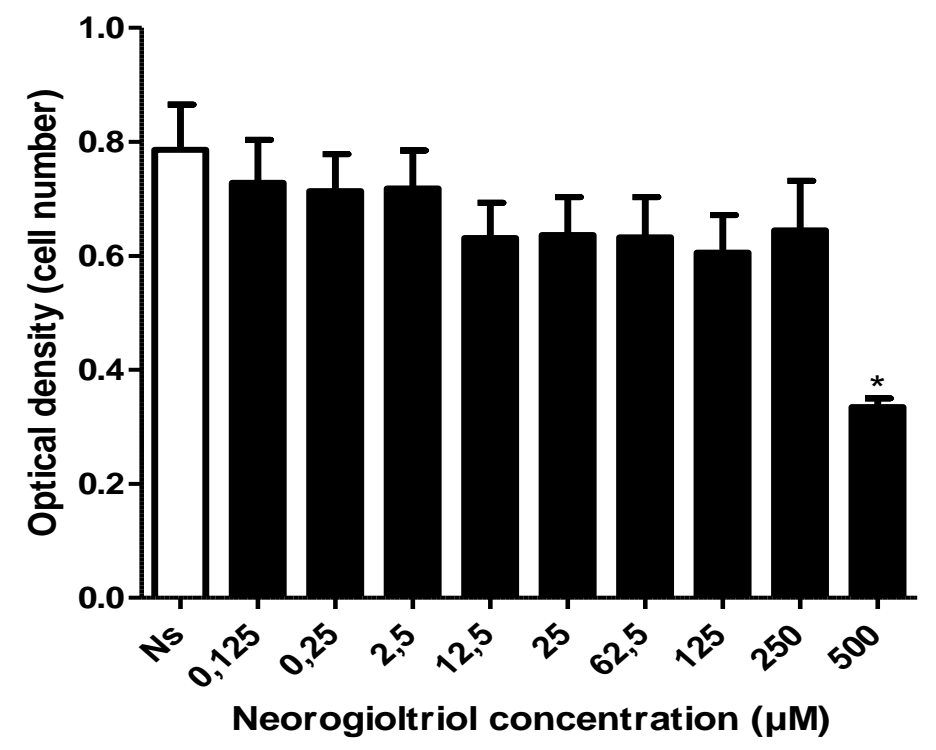

2.3. Effect of Neorogioltriol on TNFa Release, NO Production and COX-2 Expression in LPS-Stimulated Raw264.7 Cells

Carrageenan-induced rat paw edema has been fully characterized and shown to be associated with the production of several inflammatory mediators $[18,19]$ including $\mathrm{TNF} \alpha$, prostaglandins and nitric oxide release [20-22].

We first analyzed the effects of neorogioltriol in vitro, on different inflammatory molecules starting with TNF $\alpha$. The release of TNF $\alpha$ was measured using ELISA assay in the supernatant of LPS-stimulated Raw264.7 cells, pre-treated or not with neorogioltriol for $30 \mathrm{~min}$. The treatment of resting Raw264.7 cells with LPS increased the production of TNF $\alpha$. For all the concentrations tested, neorogioltriol significantly inhibited TNF $\alpha$ production (Figure 2). 
Figure 2. Effects of neorogioltriol on lipopolysaccharide (LPS)-induced tumor necrosis factor-alpha $(\mathrm{TNF} \alpha)$ production in Raw264.7 cells. Cells were treated with different concentrations ranging from $0.125 \mu \mathrm{M}$ to $62.5 \mu \mathrm{M}$ of neorogioltriol for 30 min prior to LPS (100 ng/mL) stimulation. Supernatants were collected $24 \mathrm{~h}$ later and cytokine content was measured by ELISA. Results are expressed as mean values of three independent experiments performed in duplicates, \pm standard deviation. Statistically significant differences $(p<0.003)$ between all groups are verified by the Kruskal-Wallis non-parametric test.

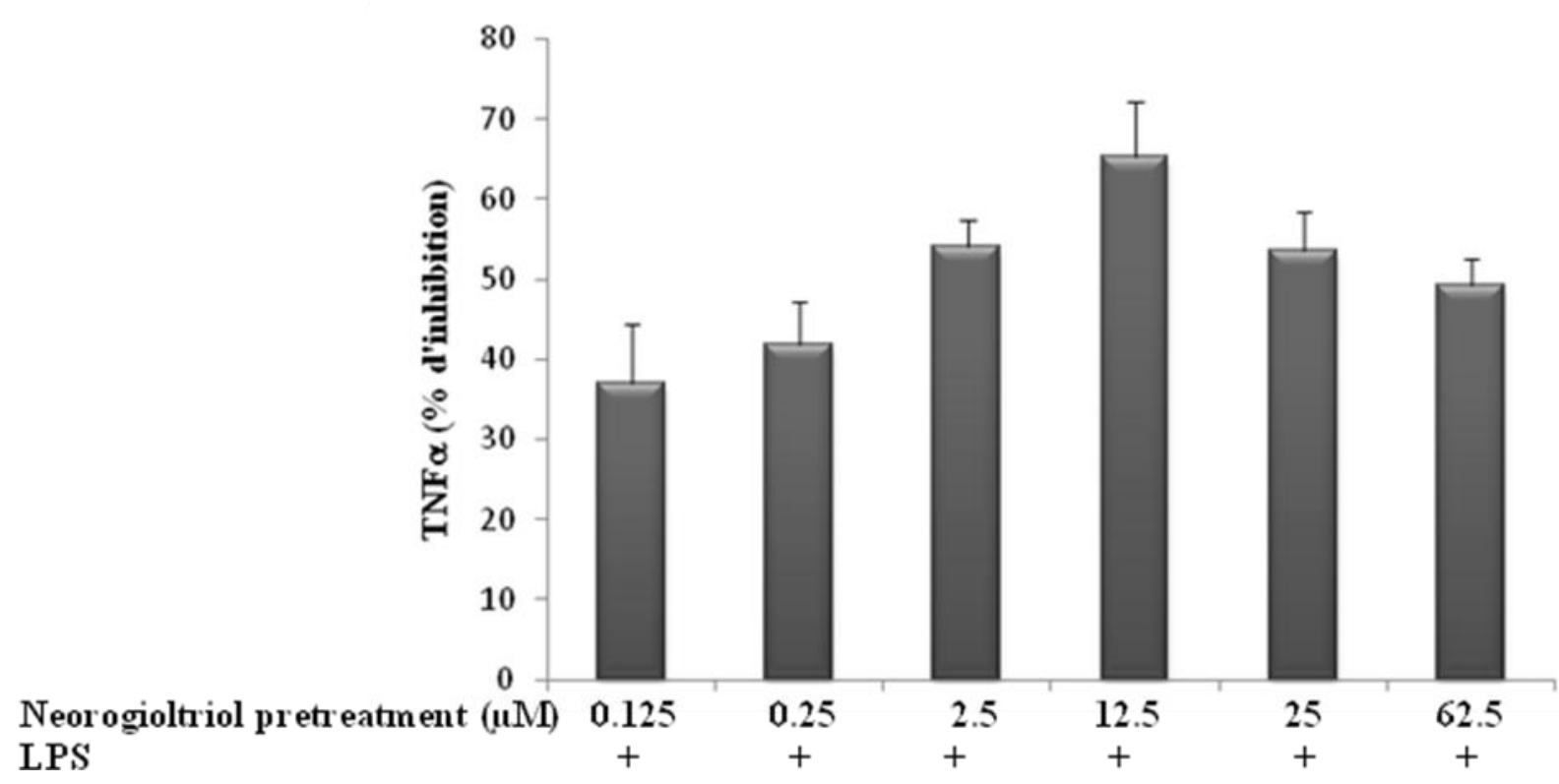

Cyclooxygenase-2 (COX-2) is the key enzyme regulating the production of prostaglandins, the central mediators of inflammation. On the other hand, iNOS activation induces massive NO production at the site of inflammation. We thus investigated the effect of our molecule on LPS-induced COX-2 expression by Western blot and on NO production by measuring the released nitrite in the culture medium by Griess reaction.

Our results show that in murine Raw264.7 cells, LPS treatment (100 ng/mL for $24 \mathrm{~h})$ induces the expression of COX-2 (Figure 3A) and increases NO production 30-fold, as compared to controls. After neorogioltriol pretreatment, the LPS-induced nitrite release was inhibited. At concentrations ranging from $0.125 \mu \mathrm{M}$ to $12.5 \mu \mathrm{M}$, neorogioltriol significantly reduced the level of NO production. However, for neorogioltriol concentrations above $25 \mu \mathrm{M}$ the curve of NO release turns upward and at $62.5 \mu \mathrm{M}$ $(25 \mu \mathrm{g} / \mathrm{mL})$ of neorogioltriol, NO release is almost similar to untreated cells (Figure 3A).

The expression of COX-2 was also tested in cells treated with $12.5 \mu \mathrm{M}, 25 \mu \mathrm{M}$ and $62.5 \mu \mathrm{M}$ neorogioltriol prior to LPS stimulation. Consistent with the inhibitory effect on NO release, the results (Figure 3B) show that neorogioltriol up to $25 \mu \mathrm{M}$ inhibited the LPS induced COX-2 expression. However, at $62.5 \mu \mathrm{M}$ the COX-2 expression is partially restored.

Taken together, our data show that, whereas neorogioltriol has no effect by itself (data not shown), this molecule inhibits the expression of $\mathrm{TNF} \alpha$ and COX-2 and the production of NO induced by LPS stimulated Raw264.7 cells. Neorogioltriol however, shows a biphasic effect since this molecule 
fails to inhibit the expression of key inflammatory mediators, such as COX-2 and NO at the highest concentrations.

Figure 3. (A) The effects of neorogioltriol on LPS-induced nitric oxide (NO) released in Raw264.7 cells. Cells were treated with different concentrations ranging from $0.125 \mu \mathrm{M}$ to $62.5 \mu \mathrm{M}$ of neorogioltriol for $30 \mathrm{~min}$ and then LPS $(100 \mathrm{ng} / \mathrm{mL})$ was added. Supernatants were collected $24 \mathrm{~h}$ later and NO content was measured by ELISA. Results were mean values of three independent experiments, performed in duplicates, \pm standard deviation. Statistically significant differences $(p<0.038)$ between all groups are verified by the Kruskal-Wallis non-parametric test; (B) The effects of neorogioltriol on LPS-induced COX-2 expressions in Raw264.7 cells. Cells were treated with different concentrations (12.5 $\mu \mathrm{M}, 25 \mu \mathrm{M}$ and $62.5 \mu \mathrm{M})$ of neorogioltriol for $30 \mathrm{~min}$; then, LPS (100 $\mathrm{ng} / \mathrm{mL}$ ) was added and the cells were incubated for $24 \mathrm{~h}$. Total cellular proteins were resolved by SDS-PAGE, transferred to nitrocellulose membranes, and detected with specific antibodies, as described in the Experimental Section. A representative immunoblot of three separate experiments is shown.

(A)

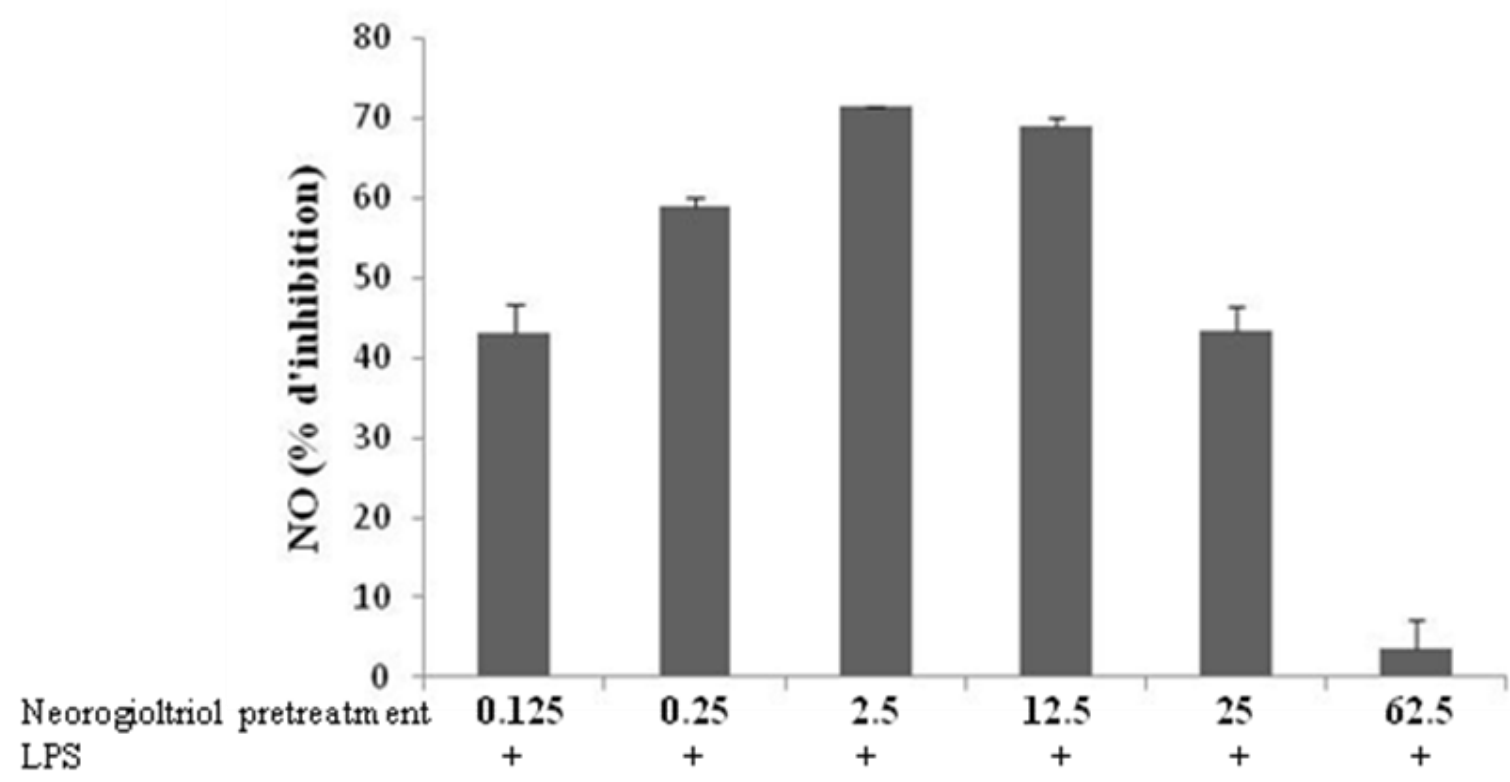

(B)

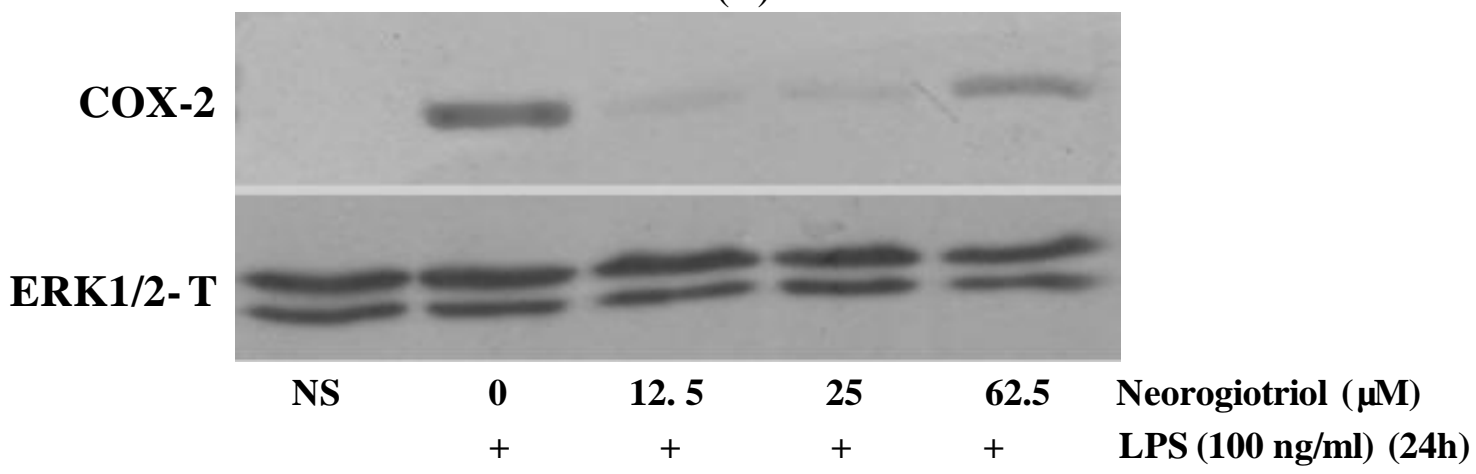




\subsection{Effects of Neorogioltriol on NF- $\kappa B$ Transactivation in LPS-Stimulated Raw264.7 Cells}

The anti-inflammatory potential of terpenes has been linked to their capacity to suppress NF- $\mathrm{B}$ signaling [4,23] which coordinates the expression of proinflammatory enzymes and cytokines including iNOS, COX-2 and TNFa [24-26]. Neorogioltriol was thus evaluated in vitro for its ability to inhibit LPS-mediated NF- $\kappa \mathrm{B}$ transcriptional activity. Raw264.7 cells, stably transfected with pNF- $\kappa \mathrm{B}-$ luc plasmid, containing three NF- $\kappa \mathrm{B}$ target sequences linked upstream to the luciferase reporter gene, were either stimulated with LPS or treated with different concentrations of neorogioltriol prior to LPS stimulation. Our result shows that LPS induces NF- $\mathrm{B}$ activation. The pre-treatment with neorogioltriol prior to LPS stimulation significantly decreased LPS induced NF- $\mathrm{B}$ transactivation (Figure 4). This result shows that the anti-oedematogenic effect of neorogioltriol correlates with the suppression of $\mathrm{NF}-\kappa \mathrm{B}$ activation.

However, despite reducing NF- $\mathrm{B}$ activity, high concentrations of neorogioltriol fail to inhibit the expression of certain NF- $\mathrm{kB}$-dependent genes that are relevant to the inflammatory process, such as COX-2. These results suggest that the observed loss of anti-inflammatory efficacy at high doses of neorogioltriol was independent of NF- $\mathrm{B}$ or indirectly dependent on NF- $\kappa \mathrm{B}$ inhibition.

Figure 4. The inhibition of $\mathrm{NF}-\kappa \mathrm{B}$ activation by neorogioltriol. Cells were stably transfected with a pNF- $\kappa \mathrm{B}-\mathrm{Luc}$ reporter and then were pretreated for $30 \mathrm{~min}$ with different concentrations $(12.5 \mu \mathrm{M}, 25 \mu \mathrm{M}$ and $62.5 \mu \mathrm{M})$ of neorogioltriol. LPS (100 $\mathrm{ng} / \mathrm{mL})$ was then added and the cells were further incubated for 6 hours. The cells were harvested and luciferase activities were determined in cell lysates and normalized to protein content using a luminometer TD-20/20 (Promega, charbonnieres, France). Results are representative of three different experiments and are expressed as the fold increase in luciferase activity induced by the specific experimental condition, relative to the luciferase activity measured in LPS stimulated cells. Statistically significant differences $(p<0.01)$ between all groups are verified by the Kruskal-Wallis non-parametric test.

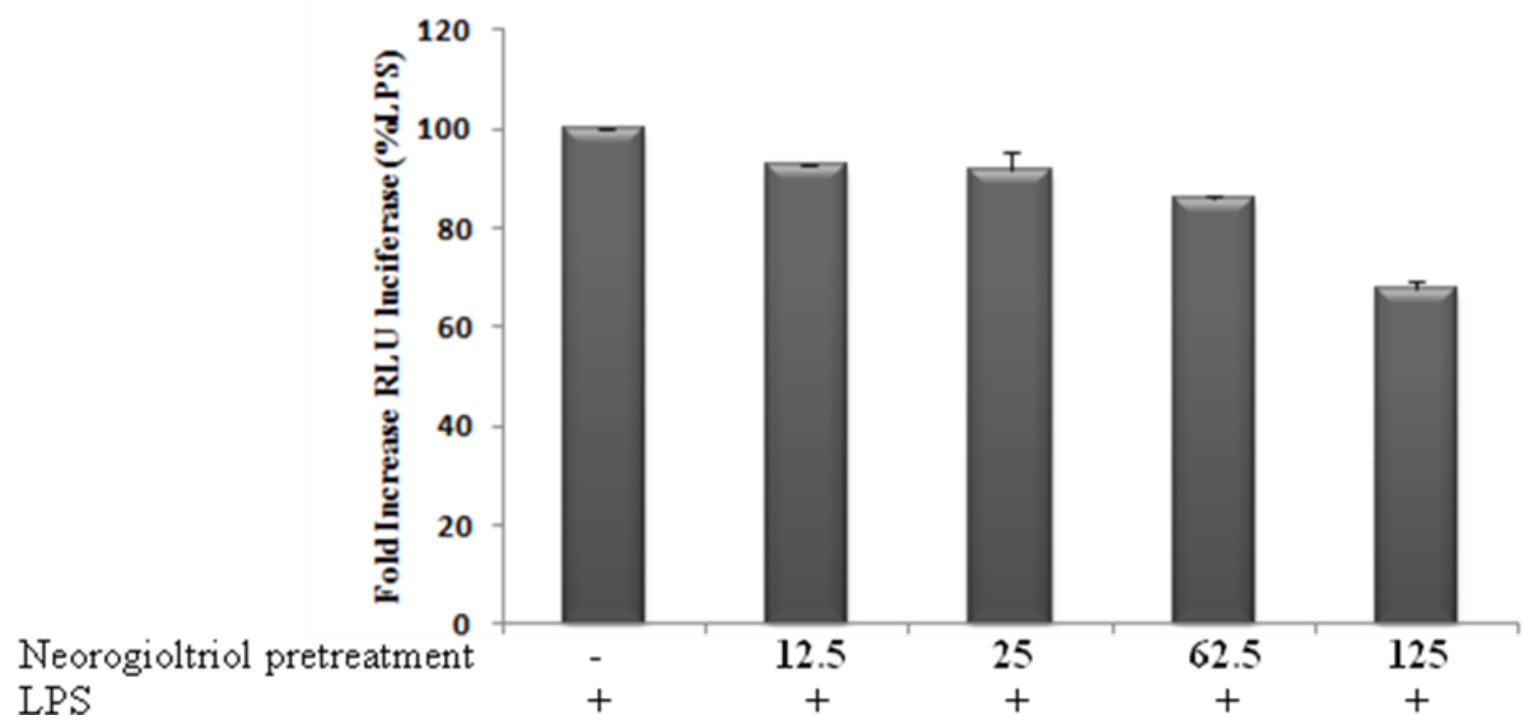




\subsection{Effect of Neorogioltriol on MAPK in LPS-Stimulated Raw264.7 Cells}

The mitogen-activated protein (MAP) kinases play a key role in the regulation of cellular response to cytokines and stresses and are also known to be important for NF- $\kappa \mathrm{B}$ activation. We thus tested whether the observed loss of anti-inflammatory efficacy may be mediated through MAPK activation.

We first studied the effect of neorogioltriol on LPS-induced MAPK activation. Our results show that at the highest concentrations used $(25 \mu \mathrm{M}$ and $62.5 \mu \mathrm{M})$, the neorogioltriol molecule fails to interfere with LPS-dependent ERK activation and only slightly inhibited the p38 MAPK phosphorylation (Figure 5). Moreover, the inhibition of MAPK pathways by PD98059 or SB203580 treatment did not alter the capacity of neorogioltriol to inhibit the LPS-induced NF- $\kappa$ B transactivation (data not shown).

Figure 5. Effect of neorogioltriol on MAPK activation in LPS-stimulated Raw264.7 cells. Cells were pretreated for $30 \mathrm{~min}$ with $62.5 \mu \mathrm{M}$ (or $25 \mu \mathrm{M}$ ) of neorogioltriol. LPS $(100 \mathrm{ng} / \mathrm{mL})$ was then added and the cells were further incubated for indicated times. Cells were collected and subjected to Western blotting with antibodies specific for phosphorylated forms of p38 (p38MAPK-P) or ERK1/2 (ERK1/2-P). Total ERK immunoblots were shown as loading control; similar results were obtained for the two concentrations of neorogioltriol used. Results are representative of two independent experiments.
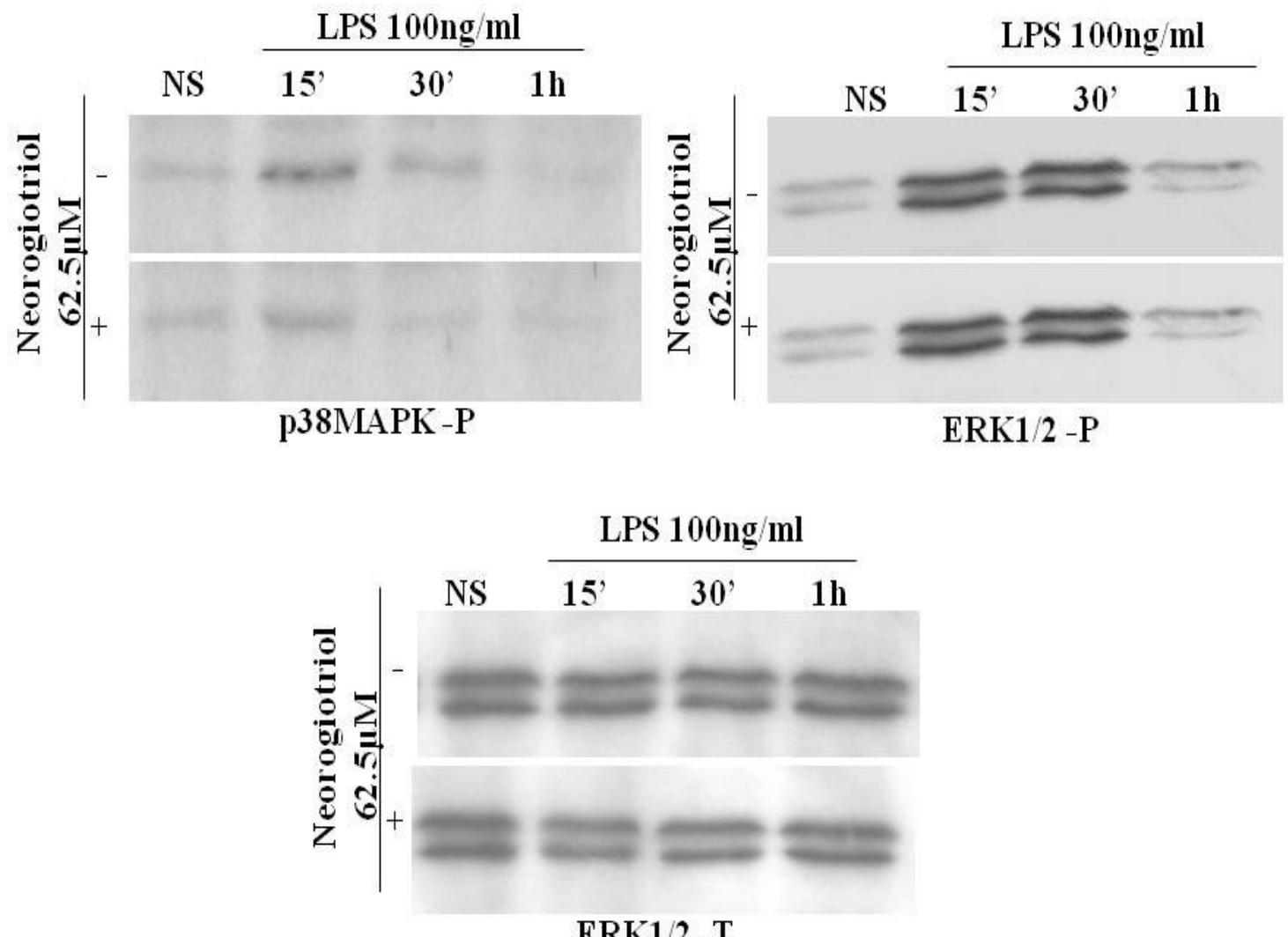

MAPKs have been reported to be involved in the LPS-induced iNOS expression signaling pathway [27] which regulates the production of NO which, in turn, may enhance the expression of COX-2. On the other hand, at the highest concentrations used, neorogioltriol does not display a 
significant inhibitory effect on MAPK phosphorylation. Using SB203580 (or PD98059), we thus tried to see whether or not MAPK activity may explain the recovery of NO release by the cells treated with the highest concentrations of neorogioltriol.

Raw264.7 cells were incubated for one hour with SB203580 (or PD98059) prior to neorogioltriol treatment and LPS stimulation. Our results show that the use of p38MAPK (or ERK1/2) inhibitor does not inhibit the recovery of NO production observed with the highest concentration of neorogioltriol (Figure 6) suggesting that abrogation of NO inhibition in the neorogioltriol treated cells is not dependent on MAPK activation.

Figure 6. Effect of p38 MAPK inhibitor on NO release in neorogioltriol treated Raw264.7 cells. Cells were pretreated for one hour with SB203580 $(10 \mu \mathrm{M})$ and then with neorogioltriol $(12.5 \mu \mathrm{M}, 25 \mu \mathrm{M}$ or $62.5 \mu \mathrm{M})$ before LPS stimulation. Supernatants were collected $24 \mathrm{~h}$ later and NO content measured by Griess reagent. Results were mean values of two independent experiments, performed in duplicate, \pm standard deviation. Comparisons between SB203580 treated and non treated cells were made using the non-parametric Mann-Whitney test, with significance of $p<0.05$.

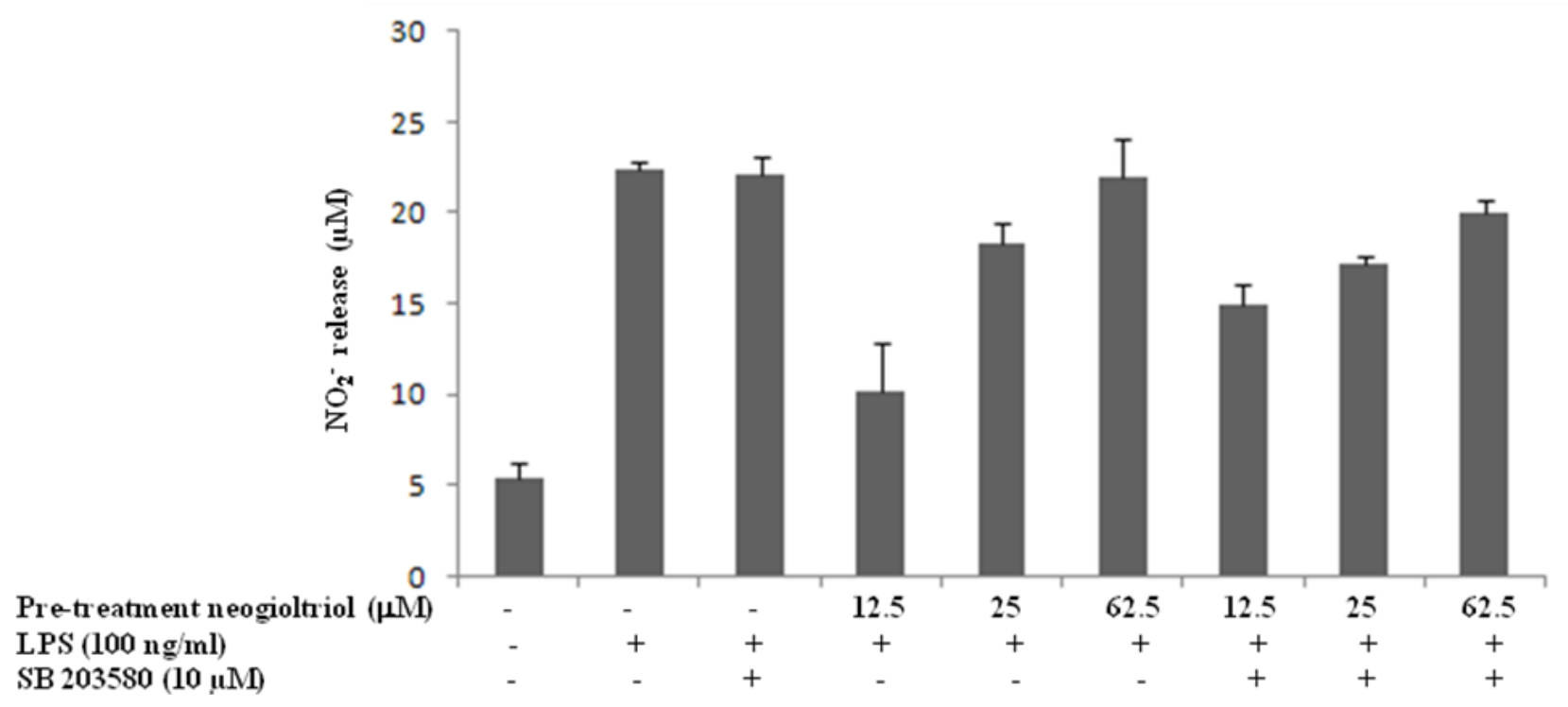

Taken together, these results show that the effect of neorogioltriol at high concentration is independent of MAPK and NF- $\kappa \mathrm{B}$. This effect may however be indirectly dependent on NF- $\kappa \mathrm{B}$ inhibition. Indeed, some non steroid anti-inflammatory drugs (NSAIDs) are known to activate COX-2 through signaling pathways independent of NF- $\kappa \mathrm{B}$ and MAPK and involving the nuclear factor PPAR $\gamma$. On the other hand, LPS has been shown to drive down PPAR $\gamma$ expression through the activation of NF- $\kappa B$ [28]. This may suggest that the repression of NF- $\kappa B$ by neorogioltriol inhibits the negative loop of NF- $\kappa \mathrm{B}$ on PPAR $\gamma$, which may allow the latter to induce the expression of NOS2 and COX-2. We are currently investigating this hypothesis. 


\section{Experimental Section}

\subsection{Isolation of Neorogioltriol}

The collection of Laurencia glandulifera and the extraction and isolation procedure of neorogioltriol have been already described [16].

\subsection{Carrageenan-Induced Paw Edema}

The anti inflammatory activity on carrageenan-induced paw edema was determined according to the method described by [29]. Naïve rats were randomly allocated to four groups and pretreated 1 hour before intraplantar administration of $100 \mu \mathrm{L}$ of $0.6 \%$ of carrageenan. (i) Control group: received $2.5 \mathrm{~mL} / \mathrm{kg}$ of vehicle (physiological solution $(0.9 \% \mathrm{NaCl})$ ) used to re-suspend the different drugs (ii) Standard group 1: received $1 \mathrm{mg} / \mathrm{kg}$ of dexamethasone $(2.5 \mathrm{~mL} / \mathrm{kg}$ ); (iii) Standard group 2: received $300 \mathrm{mg} / \mathrm{kg}$ of asprin $(2.5 \mathrm{~mL} / \mathrm{kg}$ ); and (iiii) Test group: received $1 \mathrm{mg} / \mathrm{kg}$ or $0.5 \mathrm{mg} / \mathrm{kg}$ of neorogioltriol $(2.5 \mathrm{~mL} / \mathrm{kg})$. The drugs were administrated by intraperitoneal injection. The edema volume was determined using a plethysmometer (model 7150, Ugo Basile, Italy) prior to and 1, 3 and $5 \mathrm{~h}$ after carrageenan injection. The percentage of inhibition in treated rats versus control was calculated using the following formula: EI $(\%)=\left(\left[\left(C_{\mathrm{t}}-C_{0}\right)\right.\right.$ control $-\left(C_{\mathrm{t}}-C_{0}\right)$ treated $] /\left(C_{\mathrm{t}}-C_{0}\right)$ control) $\times 100$ where $C_{\mathrm{t}}$ correspond to edema volume after carrageenan injection and $C_{0}$ correspond to edema volume before carrageenan injection.

\subsection{Reagents and Antibodies}

ERK1/2 antibodies and p38 MAPK antibodies were from Ozyme (Ozyme, Saint Quentin en Yveline, France). COX-2 antibody was from Becton Dickinson (BD Biosciences, France). PD098059, SB203580, LPS and griess reagent were purchased from Sigma (Sigma-Aldrich, Taufkirchen, Germany).

\subsection{Cells Culture}

The mouse macrophagic cell line Raw264.7 cells were obtained from American Type Culture Collection and were grown at $37{ }^{\circ} \mathrm{C}$, in RPMI 1640, supplemented with $5 \mathrm{mM}$ L-glutamine, $10 \%$ heat inactivated fetal calf serum (endotoxin-free; HyClone), penicillin $(100 \mathrm{U} / \mathrm{mL})$ and streptomycin $(100 \mu \mathrm{g} / \mathrm{mL})$.

\subsection{Cytotoxicity Test}

The MTT assay was used to test the potential toxic effects of neorogioltriol on the mouse macrophagic cell line Raw264.7 cells. Briefly, Raw264.7 cells were incubated with various concentrations of neorogioltriol for $24 \mathrm{~h}$. MTT solution was added to cell cultures at the final concentration of $0.5 \mathrm{mg} / \mathrm{mL}$ and cells were incubated for an additional $2 \mathrm{~h}$. Thereafter, medium was removed and plates were thoroughly washed with PBS. Cells were finally lysed in DMSO. The absorbance of each well at $540 \mathrm{~nm}$ was read by an automatic microplate reader. The average OD measured at different concentrations of neorogioltriol was compared using one-way analysis of 
variance (ANOVA). Proliferation of the cells exposed to the drugs was compared to the negative control. $P<0.05$ was considered statistically significant.

\subsection{Transfection and Luciferase Assay}

Raw264.7 cells were stably transfected by electroporation with an NF- $\mathrm{BB}$ luciferase reporter construct containing three NF- $\kappa \mathrm{B}$ target sequences in tandem fused to the luciferase reporter gene (3X-NF-кB-Luc), a gift from Dr J. Pierre (Faculté de pharmacy, Chatenay-Malabry, France). Cells were either left untreated or were treated with neorogioltriol at different doses for $30 \mathrm{~min}$, they were then washed and stimulated with LPS $(100 \mathrm{ng} / \mathrm{mL})$ for an additional 6 hours. Protein concentration was determined by microBCA assay. Luciferase activity was determined using a luminometer TD-20/20 (Promega, charbonnieres, France).

\subsection{Western Blot Analysis}

Cell extracts were obtained by adding $25 \mu \mathrm{L}$ of lysis buffer containing $10 \mathrm{mM}$ Tris-HCL, pH 7.5, $50 \mathrm{mM} \mathrm{NaCl}, 50 \mathrm{mM}$ sodium fluoride $(\mathrm{NaF}), 2 \mathrm{mM}$ EDTA, $1 \mathrm{mM}$ ethylene glycol-bis ( $\beta$-aminoethylether)- $N, N, N^{\prime}, N^{\prime}$-tetraacetic acid (EGTA), $2 \%$ Nonidet-P40 (NP-40), 0.75\% sodium deoxycholate (DOC), $1 \mathrm{mM}$ orthovanadate, $1 \mu \mathrm{g} / \mathrm{mL}$ aprotinine, $1 \mathrm{mM}$ PMSF, $1 \mathrm{mM}$ DTT. After $30 \mathrm{~min}$ incubation on ice, the extracts were centrifuged at 15,000 rpm for $20 \mathrm{~min}$. $25 \mu \mathrm{g}$ of whole cell lysates were resolved by electrophoresis in a $12 \%$ SDS-polyacrylamide gel. Resolved proteins were electrophoretically transferred onto PVDF sheets (Hybond-P; Amersham) and membranes were blocked by incubation in 3\% non-fat milk and $0.1 \%$ Tween in PBS for $1 \mathrm{~h}$ at room temperature followed by incubation with COX-2 antibody in 0.1\% Tween-PBS. Bound antibody was detected by incubation with horseradish peroxidase-coupled secondary antibody (Amersham Pharmacia Biotech., Buckinghamshire, UK). To ensure equal loading, the blots were then stripped (62.5 mM Tris, $\mathrm{pH} 6.8$ ), $0.1 \mathrm{M} \beta$-mercaptoethanol, 2\% SDS) and re-probed with ERK1/2 antibody.

\subsection{Measurements of Nitrite Production and Cytokine Assays}

Macrophage cells were seeded in 24 wells, treated with different concentrations of neorogioltriol or vehicle for $30 \mathrm{~min}$ and then incubated with $100 \mathrm{ng} / \mathrm{mL}$ of LPS for $24 \mathrm{~h}$. NO production in culture supernatant was spectrophotometrically evaluated by measuring nitrite, an oxidative product of NO. Nitrites were measured by Griess reaction by mixing $50 \mu \mathrm{L}$ of culture supernatant with $50 \mu \mathrm{L}$ of griess reagent. Absorbance was measured in microplates at $540 \mathrm{~nm}$ against a calibration curve with sodium nitrite standard. Supernatants were also analysed for TNF $\alpha$ content using BD Pharmingen (BD Biosciences, France) antibodies. The assays were performed according to the manufacturer's instructions.

\subsection{Statistical Analysis}

For TNF $\alpha$ production, NO release and NF- $\kappa B$ activation, the Kruskal-Wallis test was used to analyze significant differences between groups. The comparison between the two groups (presence or 
absence of SB203580) was performed using the Mann-Whitney test. For all statistical comparisons a $p$ value $<0.05$ was defined as significant.

\section{Conclusions}

As far as could be ascertained, this is the first report that shows anti-inflammatory activity for a purified algal metabolite. We have demonstrated that, in addition to its analgesic activity [16], neorogioltriol exhibits anti-inflammatory activity in vivo. This effect may be explained by the capacity of neorogioltriol, at all concentrations tested, to inhibit NF- $\mathrm{B}$ transactivation and TNF $\alpha$ release. The inhibitory effect of this compound on COX-2 expression and NO release is likely to reinforce the anti-inflammatory effect of neorogioltriol at concentrations below $62.5 \mu \mathrm{M}$. However, the exact mechanism of neorogioltriol action needs to be clarified and the target molecule in the cell identified.

\section{Acknowledgements}

This work was supported by the Ministry for High Education and Scientific Research (Tunisia). The authors wish to acknowledge N. Bahi-Jabber for assistance with the statistical analysis.

\section{References}

1. Balunas, M.J.; Kinghorn, A.D. Drug discovery from medicinal plants. Life Sci. 2005, 78, 431-441.

2. Jha, R.K.; Zi-rong, X. Biomedical compounds from Marine organisms. Mar. Drugs 2004, 2, 123-146.

3. Mayer, A.M.; Rodriguez, A.D.; Berlinck, R.G.; Hamann, M.T. Marine pharmacology in 2005-6: Marine compounds with anthelmintic, antibacterial, anticoagulant, antifungal, anti-inflammatory, antimalarial, antiprotozoal, antituberculosis, and antiviral activities; affecting the cardiovascular, immune and nervous systems, and other miscellaneous mechanisms of action. Biochim. Biophys. Acta 2009, 1790, 283-308.

4. Salminen, A.; Lehtonen, M.; Suuronen, T.; Kaarniranta, K.; Huuskonen, J. Terpenoids: natural inhibitors of NF-кB signaling with anti-inflammatory and anticancer potential. Cell Mol. Life Sci. 2008, 65, 2979-2999.

5. Folmer, F.; Jaspars, M.; Dicato, M.; Diederich, M. Marine natural products as targeted modulators of the transcription factor NF- $\kappa$ B. Biochem. Pharmacol. 2008, 75, 603-617.

6. Konig, G.M.; Wright, A.D. Sesquiterpene content of the antibacterial dichloromethane extract of the marine red alga Laurencia obtusa. Planta Med. 1997, 63, 186-187.

7. Iliopoulou, D.; Mihopoulos, N.; Vagias, C.; Papazafiri, P.; Roussis, V. Novel cytotoxic brominated diterpenes from the red alga Laurencia obtusa. J. Org. Chem. 2003, 68, 7667-7674.

8. Kladi, M.; Vagias, C.; Stavri, M.; Rahman, M.M.; Gibbons, S.; Roussis, V. C15 acetogenins with antistaphylococcal activity from the red alga Laurencia glandulifera. Phytochem. Lett. 2008, 1, 31-36.

9. El Sayed, K.A.; Dunbar, D.C.; Perry, T.L.; Wilkins, S.P.; Hamann, M.T.; Greenplate, J.T. Marine natural products as prototype insecticidal agents. J. Agric. Food Chem. 1997, 45, 2735-2739. 
10. Vairappan, C.S. Potent antibacterial activity of halogenated metabolites from Malaysian red algae, Laurencia majuscula (Rhodomelaceae, Ceramiales). Biomol. Eng. 2003, 20, 255-259.

11. Jung, W.K.; Choi, I.; Oh, S.; Park, S.G.; Seo, S.K.; Lee, S.W.; Lee, D.S.; Heo, S.J.; Jeon, Y.J.; Je, J.Y.; et al. Anti-asthmatic effect of marine red alga (Laurencia undulata) polyphenolic extracts in a murine model of asthma. Food Chem. Toxicol. 2009, 47, 293-297.

12. Guzman, S.; Gato, A.; Calleja, J.M. Antiinflammatory, analgesic and free radical scavenging activities of the marine microalgae Chlorella stigmatophora and Phaeodactylum tricornutum. Phytother. Res. 2001, 15, 224-230.

13. Dar, A.; Baig, H.S.; Saifullah, S.M.; Ahmad, V.U.; Yasmeen, S.; Nizamuddin, M. Effect of seasonal variation on the anti-inflammatory activity of Sargassum wightii growing on the N. Arabian Sea coast of Pakistan. J. Exp. Mar. Biol. Ecol. 2007, 351, 1-9.

14. Jin, D.Q.; Lim, C.S.; Sung, J.Y.; Choi, H.G.; Ha, I.; Han, J.S. Ulva conglobata, a marine algae, has neuroprotective and anti-inflammatory effects in murine hippocampal and microglial cells. Neurosci. Lett. 2006, 402, 154-158.

15. Yoon, W.J.; Ham, Y.M.; Kim, K.N.; Park, S.Y.; Lee, N.H.; Hyun, C.G.; Lee, W.J. Anti-inflammatory activity of brown alga Dictyota dichotoma in murine macrophage Raw264.7. J. Med. Plants Res. 2009, 3, 1-8.

16. Chatter, R.; Kladi, M.; Tarhouni, S.; Maatoug, R.; Kharrat, R.; Vagias, C.; Roussis, V. Neorogioltriol: A brominated diterpene with analgesic activity from Laurencia glandulifera. Phytochem. Lett. 2009, 2, 25-28.

17. Holsapple, M.P.; Schnur, M.; Yim, G.K. Pharmacological modulation of edema mediated by prostaglandin, serotonin and histamine. Agents Actions 1980, 10, 368-373.

18. Di Rosa, M.; Giroud, J.P.; Willoughby, D.A. Studies of the acute inflammatory response induced in rat in different sites by carrageenan and turpentine. J. Pathol. 1971, 104, 15-29.

19. Garcia Leme, J.; Hamamura, L.; Leite, M.P.; Rocha e Silva, M. Pharmacological analysis of the acute inflammatory process induced in the rat's paw by local injection of carrageenin and by heating. Br. J. Pharmacol. 1973, 48, 88-96.

20. Cunha, F.Q.; Poole, S.; Lorenzetti, B.B.; Ferreira, S.H. The pivotal role of tumour necrosis factor alpha in the development of inflammatory hyperalgesia. Br. J. Pharmacol. 1992, 107, 660-664.

21. Salvemini, D.; Wang, Z.Q.; Wyatt, P.S.; Bourdon, D.M.; Marino, M.H.; Manning, P.T.; Currie, M.G. Nitric oxide: a key mediator in the early and late phase of carrageenan-induced rat paw inflammation. Br. J. Pharmacol. 1996, 118, 829-838.

22. Omote, K.; Hazama, K.; Kawamata, T.; Kawamata, M.; Nakayaka, Y.; Toriyabe, M.; Namiki, A. Peripheral nitric oxide in carrageenan-induced inflammation. Brain Res. 2001, 912, 171-175.

23. de las Heras, B.; Hortelano, S. Molecular basis of the anti-inflammatory effects of terpenoids. Inflamm. Allergy Drug Targets 2009, 8, 28-39.

24. Xie, Q.W.; Kashiwabara, Y.; Nathan, C. Role of transcription factor NF- $\kappa B / R e l$ in induction of nitric oxide synthase. J. Biol. Chem. 1994, 269, 4705-4708.

25. Chen, F.; Kuhn, D.C.; Sun, S.C.; Gaydos, L.J.; Demers, L.M. Dependence and reversal of nitric oxide production on NF- $\mathrm{BB}$ in silica and lipopolysaccharide-induced macrophages. Biochem. Biophys. Res. Commun. 1995, 214, 839-846. 
26. Schmedtje, J.F., Jr.; Ji, Y.S.; Liu, W.L.; DuBois, R.N.; Runge, M.S. Hypoxia induces cyclooxygenase-2 via the NF- $\mathrm{BB}$ p65 transcription factor in human vascular endothelial cells. J. Biol. Chem. 1997, 272, 601-608.

27. Chen, C.C.; Wang, J.K. p38 but not p44/42 mitogen-activated protein kinase is required for nitric oxide synthase induction mediated by lipopolysaccharide in Raw264.7 macrophages. Mol. Pharmacol. 1999, 55, 481-488.

28. Necela, B.M.; Su, W.; Thompson, E.A. Toll-like receptor 4 mediates cross-talk between peroxisome proliferator-activated receptor gamma and nuclear factor- $\kappa \mathrm{B}$ in macrophages. Immunology 2008, 125, 344-358.

29. Winter, C.A.; Risley, E.A.; Nuss, G.W. Carrageenin-induced edema in hind paw of the rat as assay for anti-inflammatory drug. Proc. Soc. Exp. Biol. Med. 1962, 111, 544-547.

Samples Availability: Available from the authors.

(C) 2011 by the authors; licensee MDPI, Basel, Switzerland. This article is an open access article distributed under the terms and conditions of the Creative Commons Attribution license (http://creativecommons.org/licenses/by/3.0/). 